\title{
Factors Affecting Groundnut Exports in The Gambia: The Vector Error Correction Approach
}

\author{
Baseedy Bojang ${ }^{12 *}$ \\ 1.Faculty of Forestry and Environment, Universiti Putra Malaysia, 43400 Seri Kembangan, Selangor, Malaysia \\ 2.Department of Economics and Finance, University of The Gambia, MDI Road, Kanifing South, The Gambia
}

\begin{abstract}
Groundnut, a leguminous oil seed grown in the uplands serve as food and main export crop in The Gambia. Despite a long tradition of groundnut farming, practical knowledge, favorable climatic conditions, and suitable land, recent declines in production and exports have hampered groundnut farming's contribution to poverty reduction, food security, and income generation. Revitalization of cash crop, such as groundnut has emerged as a national priority, embraced on a daily basis by rural development actors, particularly famers seeking to improve and secure their income. Thus, groundnut appears to be obvious and necessary, not only for farmers' income security, but also for the country's ability to attract foreign currency, provide livestock feed, and develop national trade. Given the country's poor performance in groundnut exports, we deem it necessary to identify the key factors influencing that performance and study their effects on groundnut export earnings in order to draft appropriate policies aimed at increasing exports earnings in The Gambia. This paper employs the cointegration approach, with export value serving as the independent variable, to examine the country's export performance over a 49-year period using time series data (1970-2018). Once a cointegration vector between the variables is discovered, the Vector Error Correction Model is applied. The findings reveal that nominal exchange rate, producer price are key factors affecting significantly the country's export performance in short-run. Furthermore, in the long-run exchange rate, production, producer price, and world export price are significant factors determining groundnut export earnings in The Gambia. To increase the country's market share and export earnings, especially in the long-run, it is recommended to ensure an effective transmission of international prices increments to farmers and to improve the production by raising yields significantly.
\end{abstract}

Keywords: Determinants of Agricultural Exports, Agricultural Exports, Cointegration, Groundnut, The Gambia DOI: $10.7176 / \mathrm{DCS} / 11-8-04$

Publication date:October $31^{\text {st }} 2021$

\section{Introduction}

Since time immemorial rural population in The Gambia depends on groundnut as a means of livelihood, it serves as food and main export crop, contribute to poverty reduction and food security. Groundnut is Gambia's main export crop, accounting for 66 percent of the country's agricultural export earnings. Around $70 \%$ of the active labor force is employed in manufacturing, handling, distribution, and marketing of groundnut. Groundnut farming takes approximately 45 percent of agricultural land on an annual basis, employs approximately 80 percent of farm households, accounts for 60-80 percent of farm income, and contributes approximately 24 percent to agricultural GDP in 1960s. In addition, the groundnut sector in The Gambia possesses promising aspects including good prospects; favorable climatic conditions; availability of suitable land; availability of labor supply; traditional and practical knowledge of groundnut farming, high demand in both domestic and international markets; proximity to western Europe and other markets; availability of proven aflotoxin resistant seed and varieties; river transportation for timely evacuation of nuts; and support for private sector development of the value chain. Furthermore, once groundnuts are harvested, the aerial parts (leaves and stem) of the plants are taken in large quantities and used as nutritious livestock feed, either fresh or dried (groundnut straw).

However, the sector has recently seen a decline in production, export value, agricultural export share, and total export share, resulting in food insecurity and an increase in rural poverty from 64.2 percent in 2010 to 69.5 percent in 2015. (Integrated Household Survey, (GBoS 2015/2016). This situation has posed a threat to the county's economy, which is heavily reliant on agricultural exports. For this reason, the government of The Gambia has taken steps through its policies to revitalize the sector. Given the tremendous opportunities mention above in the groundnut sector, it turns out that production and export of groundnut has enormous potential to contribute to poverty reduction, food security, economic growth, and a source of income for many farmers. Notwithstanding this study's attempt to determine the factors and their effects on groundnut exports in The Gambia, no econometrical study on these exports in The Gambia has been conducted. This current study proves to be important in providing information on the factors influencing groundnut exports in The Gambia, as well as inciting conductive actions aimed at increasing export earnings.

According FAO statistics, groundnut share of total agricultural export earnings reduced from $58 \%$ in 2000 to $13 \%$ in 2018 . Likewise groundnut share of total export value reduced from $47 \%$ in 2000 to $1 \%$ in 2018 . The buyers of The Gambia groundnut are concentrated in Europe such as Netherlands, United Kingdom, Spain, 
Belgium and Luxembourg. Groundnuts serve as the base for wide range of products according to scientist, raw groundnut can be used to make 63 different products. Therefore, investment in groundnut production in The Gambia has the potential not only to export raw nuts, but also to consider processing activities that would allow development and sale of value-added products at a premium price.

Table 1 shows the quantity, value, and share of groundnut export from 2009 to 2018. Groundnut exports accounted for about $15 \%$ of agricultural export and 5\% of the country's overall exports value on average between 2009 and 2018. Furthermore, the groundnut's sector $\operatorname{logRCA}$ is greater than one, indicating the country's competitiveness in groundnut exports.

Table 1. Groundnut export quantities and value in The Gambia (2009-2018)

\begin{tabular}{|l|l|l|l|l|l|l|}
\hline Years & $\begin{array}{l}\text { Quantity } \\
\text { (ton) }\end{array}$ & $\begin{array}{l}\text { Value } \\
(1000 \text { USD) }\end{array}$ & $\begin{array}{l}\text { Unit value } \\
(\$ / \text { ton) }\end{array}$ & $\begin{array}{l}\text { Share in } \\
\text { agricultural } \\
\text { exports value } \\
(\%)\end{array}$ & $\begin{array}{l}\text { Share in total } \\
\text { exports } \\
\text { value (\%) }\end{array}$ & $\begin{array}{l}\text { Export } \\
\text { performance } \\
\text { logRCA }\end{array}$ \\
\hline 2009 & 18,000 & 9,200 & 511 & 24 & 14 & 6.75 \\
\hline 2010 & 7,558 & 5,852 & 774 & 21 & 17 & 7.01 \\
\hline 2011 & 2,224 & 1,900 & 854 & 8 & 2 & 4.98 \\
\hline 2012 & 1,422 & 1,626 & 1,143 & 6 & 2 & 4.51 \\
\hline 2013 & 4,148 & 2,224 & 536 & 10 & 2 & 5.23 \\
\hline 2014 & 534 & 2,500 & 4,682 & 18 & 2 & 3.66 \\
\hline 2015 & 5,275 & 3,871 & 734 & 20 & 4 & 5.89 \\
\hline 2016 & 7,689 & 6,151 & 800 & 16 & 7 & 4.94 \\
\hline 2017 & 1,881 & 1,518 & 807 & 13 & 1 & 4.50 \\
\hline 2018 & 1,400 & 1,500 & 1,071 & 13 & 1 & 4.79 \\
\hline Average & 5,013 & 3,634 & 1,191 & 15 & 5.29 & 5.23 \\
\hline
\end{tabular}

Source: FAOSTAT, 2021

Note: RCA: Revealed Comparative Advantage $=\left(X_{i j} / X_{i t}\right) /\left(X_{n j} / X_{n t}\right)$, where $X_{n j}$ : value of world export of groundnut, $\mathrm{X}_{\mathrm{ij}}$ : value of groundnut from The Gambia, $\mathrm{X}_{\mathrm{it}}$ : total value of agricultural exports from The Gambia, $\mathrm{X}_{\mathrm{nt}}$ : total value of world agricultural export. When $\log \mathrm{RCA}>1$ the country is competitive in the commodity being exported (Balasa,1965) .

This research uses the cointegration method to examine the primary determinants affecting groundnut exports in The Gambia, to scrutinize their effects, and analyze the causality between them. The following are the study's specific objectives

1. To identify key internal and external factors driving groundnut exports in The Gambia from 1970 to 2018 ,

2. To quantify and analyze the magnitude of these factor's impact on export performance, and

3. To inform relevant policy prescription and recommendations on agricultural trade based on the findings. The article is organized as follow: in Section 2, discussed briefly agricultural and groundnut sector in The Gambia and Sub-Saharan Africa, section 3 review the factors influencing agricultural export in Sub -Saharan Africa (SSA), section 4 presents econometric methodology and data description used in this study, and section 5 reports findings and discussion. The final section presents conclusions and recommendations.

\section{Overview of Groundnut Sector in The Gambia and Sub-Saharan Africa}

Groundnut exports have long been a major source of revenue for number of African counties, dating back to the colonial period. Groundnut production and trade were promoted as a key part of agricultural colonial policies in Africa because of rising European demand for vegetable oil and industrial oils and fats (for lubricants and production of soaps and candle). For example, by 1947, the British had launched the East African Groundnut Scheme, which was designed to clear nearly 3.2 million acres of land in East Africa in order to grow 600,000 to 800,000 tons of groundnuts to aid Britain's post war economic recovery (Morgan 2007).

Groundnut production in Africa increased dramatically after WWII, owing to high market prices, relatively consistent rainfall, and good domestic policies. In The Gambia, for example, the implementation of "oxenisation program" which introduced draft animals in 1955, alleviate labor shortage and aided in the expansion of groundnut production (Diaz et al. 2008).

Sub-Saharan Africa accounted for just under 89 percent of global groundnut exports, with Nigeria accounting for 46 percent of the total and Senegal and Sudan accounting for one-fourth of Global trade, and the trend continued in the1970s. During 1980s, African's role in the international raw groundnut trade changed dramatically; two decades later, Africa's share of global raw groundnut commodity trade had dropped to low single digit due to implementation of aflatoxin standards by most European Union members. A combination of macroeconomics factors, climatic shocks, adverse sector-specific policies in the leading producer/exporting countries, and market developments, such as the emergence of new global suppliers that gained market share on the basis of competitive cost, quality ,and supply reliability, contributed Africa's trade collapsed. 
Badiane and Kinteh (1994), for example, attribute the declined of African raw groundnut exports to macroeconomic and sectoral policies that reduces producers incentives through direct or indirect taxation. In The Gambia, Senegal and Sudan, overvaluation of country exchange rates resulted in net taxation levels of 10 to $20 \%$, leading to reduced groundnut production and trade in those counties.

In terms of sectoral policies, the period was characterized by high level of government intervention in various aspects of groundnut production and trade ( e.g., input supply, marketing functions, and establishment of producer prices). In most SSA countries, groundnut export revenues were used to fund general development or political purposes, and the share of export prices paid to groundnut farmers decreased (Diop et al.2004).

Since the 1980s, the increasing demand for edible groundnuts has provided opportunities for new players to enter the international market. Argentina and China, in particular emerged as major groundnut suppliers, fully overtaken SSA as a sources of raw groundnut. Several newer manufacturers, such as Brazil, Nicaragua, and Vietnam, have joined the industry and achieved notable success over the last decade. In the case of SSA, after a sharp drop in exports from the 1970s to the early 1980s, raw groundnut exports from the region have been trending upwards since mid-1980s. According to FAO statistics, average total global raw groundnut production from 1994 to 2019 totaled 38,568,262.65 tons, with Asia, Africa, the Americas, and the Oceania accounting for 64\%, 27.3\%, $8.6 \%$, and $0.1 \%$, respectively.

Agriculture accounts for 30\% of GDP in The Gambia, employing 70\% of the labor force, provides $75 \%$ of total household income and serving as the backbone of economic growth, sustainable development, increased rural income, and poverty reduction (FAO 2020). It also generates about $40 \%$ foreign exchange earnings, primarily through the export of groundnuts (FAO 2020). Agricultural exports are groundnut, cotton, sesame, livestock products, forestry products, fruits, cashew, and fish among others. However cotton is the second exportable cash crop, but production and land devoted to cotton cultivation have been declining.

As a result of persistent decline in economic growth recorded in the mid-1980s, the government has taken steps to liberalize marketing and distribution of a number of cash crops, including groundnuts, as part of the Economic Recovery Program (ERP), which has resulted in the implementation of trade policy reform to salvage the economy from collapsed. Building on the ERP's success, the government introduced the Program for Sustainable Development (PSD) in 1990s. The PSD's goal is to reinforce the ERP's economic policies. The ERP was dominated by stabilization and rehabilitation. While these concerns remain in the PSD, a greater emphasis is now place on the role of private sector in achieving growth and diversification goals. This has resulted principally in restoring growth, reducing poverty and trade liberalization. The mid-1980 reforms were reinforced by Poverty Reduction Strategy Paper (PRSPs)-PRSP-1(2003) and PRSP-2 (2007), as well as the Program for Accelerated Growth and Employment (PAGE) later in 2013 resulted in reducing poverty, sustaining the economic growth and diversifying the agricultural sector. Furthermore, Gambia's newly adopted National Development Plan (NDP) 2018-21 continues to aims to promote export-led growth through sustainable agriculture and to enhance the country's international competitiveness.

Agriculture in the Gambia is dominated by subsistence-oriented rainfed crop and livestock production systems. Cereals, such as rice, millet, sorghum, and maize, are the most important food crops. The main cash crop is groundnut, but horticulture and cashews are showing promising growth prospects. Around $80 \%$ of farm households are involved in groundnut farming, which accounts for $60-80 \%$ of their income. Groundnut is the most important cash crop in terms of harvested areas and gross production value, follow by millet, rice, maize and sorghum. The total hasted area in 2018 was estimated to be 118,047 hectares with average annual growth rate of $1.12 \%$ per annum. The total production of groundnut increased from 72,557 metric tons in 2007 to 118,047 metric tons in 2018. Corresponding an annual growth rate of $7.06 \%$ per annum (FAOSTAT). This good performance relative to SSA's larger producers given that Nigeria, Senegal, Chad and Tanzania recorded an average growth rate of $5.32 \%, 23.15 \%, 15.08 \%$, and $10.6 \%$ per year respectively during the same period. At the same time Gambia recorded very good average yield in groundnut production of $8,995 \mathrm{hg} / \mathrm{ha}$ relative to major producing countries given Nigeria, Senegal, Chad and Tanzania recorded an average yield of 12,122 hg/ha, 9,248 hg/ha, 10,793 hg/ha and $8,869 \mathrm{hg} / \mathrm{ha}$ per annum respectively during the same period.

Groundnut, a leguminous oil seed grown in the uplands, is a stable food and The Gambia's main export crop. Possess promising aspects such as long tradition and practical knowledge of groundnut farming, favorable climatic conditions, abundant labor, high demand in both domestic and international markets, contribution to poverty reduction and food security. The sector is characterized by subsistence farmer/producers, processors and traders/exporters supported by several non-governmental organizations (NGOs), the government, credit institutions, financial partners, projects, programs and associations. Financial support, training, and technical services are provided to the sector's direct actors by all of these sectors and partners. 
Table 2 Groundnut production trend in The Gambia fro (2009-2018)

\begin{tabular}{|c|c|c|c|}
\hline Crop year & Area (hectare) & Production (ton) & Yield (ton/hectare) \\
\hline 2007 & 117,591 & 72,557 & 06 \\
\hline 2008 & 133,703 & 109,641 & 08 \\
\hline 2009 & 148,331 & 121,950 & 0.8 \\
\hline 2010 & 135,500 & 137,631 & 1.0 \\
\hline 2011 & 11,924 & 83,858 & 0.7 \\
\hline 2012 & 116,507 & 119,614 & 1.0 \\
\hline 2013 & 100,305 & 93,862 & 0.9 \\
\hline 2014 & 81,026 & 80,650 & 1.0 \\
\hline 2015 & 109,452 & 103,527 & 0.9 \\
\hline 2016 & 113,022 & 106,360 & 0.9 \\
\hline 2017 & 115,491 & 108,191 & 0.9 \\
\hline 2018 & 118,047 & 110,063 & 0.9 \\
\hline Average & 114,961 & 106,571 & 0.9 \\
\hline AAGR\% & 1.12 & 7.06 & - \\
\hline
\end{tabular}

Note: AAGR: average annual growth rate. Source: FAOSTAT, 2021

\section{Review of Factors Affecting Agricultural Exports in Sub-Saharan Africa}

The economics of determinants of agricultural export in developing countries after trade liberalization is still a contentious subjects. These determinants of agricultural export are typically divided into two categories: internal and external determinants (Folawewo and Alakojo, 2010; Kingu, 2014). External factors include factors such as deterioration of terms of trade, elasticity of demand for exported commodities, world income of trade partners, non-tariff and technical barriers and other factors influencing import demand. Internal factors, on the other hand, have impeded developing counties' agricultural export growth, such as domestic policies that adversely affected export supply, structural and quality of institutional arrangements, standards, access to inputs, market price, poor infrastructure, access to information, lack of agricultural export credit, a real exchange rate, agricultural productivity and agricultural export taxation ( supply side conditions).

In general, a fair share of studies investigating the determinants of agricultural export performance find that world export volume (a proxy for global export demand) is a significant factor influencing export performance in SSA. Achille et al.(2020) in analyzing factors affecting sesame seed exports in Burkina Faso using VECM for a period of 47 years (1970-2016), they found that export volume significantly affect the county's export performance in short-run. Similarly, Boansi et al. (2014) in a study analyze determinants agricultural export trade in a case of fresh pineapple from Ghana using ordinary Least square method the authors found a significant effect of export volume on pineapple export performance. Again, Boansi et al. (2014) used VECM to study cotton export for a period of 31 years, using external and supply side factors. The author found that world export volume (a proxy for world export demand) of the commodity under study and export competitiveness (as a measure by the comparative performance index) of the product significantly influence cotton lint exports from Chad and Mali.

Many studies have been conducted to determine the factors affecting exports for various agricultural commodities in SSA, and the results have been contradictory. Several studies have found output (production) to be an important factor that stimulates exports. It is regarded as a key supply side determinant of export growth. In as much as domestic production generates a surplus from which foreign exchange is earned through exports For instance Folawewo and Alakojo (2010) examined the determinants of agricultural export in Nigeria using Parsimonious error correction model using data set from 1970 to 2007. The outcome of the analyses revealed that agricultural outputs is important determinants of agricultural exports. Kingu (2014) examines the determinants of agricultural export (cotton lint) using Cointegration and error correction model in Tanzania. The author found that agricultural productivity significantly have a positive effect on cotton lint export earnings. In addition, The study by Allaro (2011) using the VECM to study the performance of oil seed export in Ethiopia, the author found that real output significantly influence export earnings.

Similarly, various studies have found that domestic exchange rate depreciation (foreign exchange rate appreciation) makes export products less expensive in the international market resulting in increased demand. Uysal and Mohamoud (2018) identify and analyze variables that influence export performance in Seven East African countries, and they propose potential solutions to improve export performance in the region. Using panel data analysis from 1990 to 2014. They found that exchange rate has positive impact on export value. Likewise a study of Kingu (2014) on the study of determinants of agricultural export (cotton lint) using cointegration and error correction model in Tanzania found a significant association between real exchanger rate and export earnings. 
The study by Allaro (2011) using the VECM to study the performance of oil seed export in Ethiopia, the findings revealed a significant positive effect of nominal exchange rate on oil seeds exports. On the contrary, Amoro et al. (2012) found a significant and negative effect of nominal exchange rate on rubber exports in Cote d'Ivoire in a study on the determinants of agricultural exports in Cote d'Ivoire using the Ordinary Least Square method.

Commodity price variable are very important drivers of exports in SSA countries, according to many studies investigating the determinants of o agricultural export performance. Prices as proposed by Dercon (1993) serve as a channel through which relevant economic policies influence production, export and income. In affirming the significance of commodity prices to export growth, Amoro et al. (2012) examine factors the influence agricultural export with specific reference to cocoa and rubber using the Ordinary Least Square method (OLS). The results revealed that producer price significantly affect the rubber exports in Cote d'Ivoire. Likewise, Allaro (2011) has done a study using the VECM on the export performance of oilseed in Ethiopia, and the author has found a significant effect of foreign export prices on oilseed. Achille et al.(2020) analyze factors affecting sesame seed exports in Burkina Faso using VECM. They found that producer price significantly affect the county's export performance in both short-run and long-run.

\section{Research Methodology}

\subsection{Model specification}

This study employed the export supply models based on Goldstein et al. (1978), which was adopted and used in numerous studies such as Alloro (2011); Kingu (2014) and Achille et al. (2020). The following function is used to identify and analyze the factors affecting groundnuts exports in The Gambia:

Xvalue $=f($ Exchrate, Prod, Pdprice, Wexprice, Wexpvol $)$

Where Xvalue is exports value or export earnings of groundnuts, Exchrate is the nominal exchange rate (between USD and local currency, GMD), Prod is the production of groundnuts, Pdprice is producers price or farm gate price of groundnuts, Wexprice is world export price or international price of groundnuts and Wexpvol is world export volume as a proxy for world demand of groundnuts.

The cointegration method is used in this study to investigate the factors that affect the groundnuts exports in The Gambia. This approach, on the other hand, is based on the stationarity of the time series variables used. Again, this techniques necessitates the integration (stationary) of the variables in the same order, as well as the existence of a stationary linear combination (C.J Granger, 1986; Malik,2010).

These requirements needs to be met, since most economic time series are not stationary at levels and any regression of such series could produce spurious, meaningless and irrelevant results ((C.J Granger, 1986), as result, the unit root test on the variables of interest is the first step in time series econometric analysis. The test determines whether or not the data series is stationary. The conventional Augmented Dickey-Fuller (ADF) test is used to test for detecting unit roots. The equation for ADF test is based on the following form.

$\Delta \mathrm{Z}_{\mathrm{t}}=\alpha_{1}+\alpha_{2} \mathrm{t}+\alpha_{3} \mathrm{Z}_{\mathrm{t}-1} \sum_{i=1}^{p} \beta_{1 i} \Delta \mathrm{Z}_{\mathrm{t}}+\mathrm{t}$

Where ADF regression tests for the presence of unit root of $Z_{t}$, the logarithm values of all models variables at time t. The null (and alternative) hypothesis that tests the presence of unit root in the variable is $\mathrm{H}_{\mathrm{O}}: \alpha_{3}:=0$ (nonstationary) against $\mathrm{H}_{1}: \alpha_{3} \neq 0$ (deterministic trend).

Based on the Vector Autoregression (VAR) and Vector Error Correlation Model (VECM) representations, the nature of stationarity indicates the presence of cointegration and causality. The cointegration test is used to determine whether or not there is a long-run relationship between variables. In contrast, lack of cointegration implies that such variables have no long-run link; and in principles they can wonder arbitrarily from each other ( Dickey, et al. 1991). The study employs the Johansen (1988) maximum likelihood ratio to test and take into account two test statistics, namely the trace statistics and the maximum eigenvalue statistics (Johansen \& Juselius, 1990). They are expressed as followed:

$$
\begin{aligned}
& \lambda_{\text {trace }}=-T \sum_{i=r+1}^{n} \log \left(1-\hat{\lambda}_{i}\right) \\
& \lambda_{\text {max }}=-T \log \left(1-\hat{\lambda}_{r+1}\right)
\end{aligned}
$$

Where $\hat{\lambda}_{r+1} \ldots \ldots . \hat{\lambda}_{n}$ are the (n-r) smallest estimated eigenvalues, The null hypothesis of r cointegrating vectors is tested here against the alternative hypothesis of $r+1$ cointegrating vectors in this paper. The cointegration would determine which model, VAR or VECM, the study would use to analyze the factors affecting groundnut exports in The Gambia. First, if the variables employed in this study are stationary and not cointegrated, the following VAR model described below must be used:

$$
\begin{gathered}
\text { Xvalue }_{\mathrm{t}}=\beta_{0}+\sum_{i=1}^{p} \beta_{1 i} \text { Xvalue }_{\mathrm{t}-\mathrm{1}}=\sum_{j=1}^{p} \beta_{2 j} \text { Exchrate }_{\mathrm{t}-\mathrm{j}}+\sum_{k=1}^{p} \beta_{3 k} \text { Prod }_{\mathrm{t}-\mathrm{k}}+\sum_{r=1}^{p} \beta_{4 r} \text { Prprice }_{\mathrm{t}-\mathrm{r}}+ \\
\sum_{n=1}^{p} \beta_{5 n} \text { Wexprice }_{\mathrm{t}-\mathrm{n}}+\sum_{m=1}^{p} \beta_{6 m} \text { Wexpvol }_{\mathrm{t}-\mathrm{m}}+\mathrm{U}_{1 \mathrm{t}}
\end{gathered}
$$




$$
\begin{gathered}
\operatorname{Prod}_{\mathrm{t}}=\Upsilon_{0}+\sum_{k=1}^{p} \quad{ }_{1 i} \operatorname{Prod}_{\mathrm{t}-\mathrm{k}}+\sum_{i=1}^{n} \quad{ }_{2 j} \text { Xvalue }_{\mathrm{t}-1}=\sum_{j=1}^{p} \quad{ }_{3 k} \text { Exchrate }_{\mathrm{t}-\mathrm{j}}+\sum_{r=1}^{p} \quad{ }_{4 r} \text { Prprice }_{\mathrm{t}-\mathrm{r}}+ \\
\sum_{n=1}^{p} \quad{ }_{5 n} \text { Wexprice }_{\mathrm{t}-\mathrm{n}}+\sum_{m=1}^{p} \quad{ }_{6 m} \text { Wexpvol }_{\mathrm{t}-\mathrm{m}}+\mathrm{U}_{1 \mathrm{t}} \quad \text { (7) }
\end{gathered}
$$

Prprice $_{\mathrm{t}}=\delta_{0}+\sum_{r=1}^{p} \delta_{1 i}$ Prprice $_{\mathrm{t}-\mathrm{r}}+\sum_{j=1}^{p} \delta_{2 j}$ Exchrate $_{\mathrm{t}-\mathrm{j}}+\sum_{k=1}^{p} \delta_{3 k}$ Prod $_{\mathrm{t}-\mathrm{k}}+\sum_{i=1}^{n} \delta_{4 r}$ Xvalue $_{\mathrm{t}-\mathrm{r}}+$

$$
\sum_{n=1}^{p} \delta_{5 n} \text { Wexprice }_{\mathrm{t}-\mathrm{n}}+\sum_{m=1}^{p} \delta_{6 m} \text { Wexpvol }_{\mathrm{t}-\mathrm{m}}+\mathrm{U}_{1 \mathrm{t}}
$$

Wexprice $_{\mathrm{t}}=\lambda_{0}+\sum_{i=1}^{p} \lambda_{1 i}$ Wexprice $_{\mathrm{t}-1}+\sum_{j=1}^{p} \lambda_{2 j}$ Exchrate $_{\mathrm{t}-\mathrm{j}}+\sum_{k=1}^{p} \lambda_{3 k} \operatorname{Prod}_{\mathrm{t}-\mathrm{k}}+\sum_{r=1}^{p} \lambda_{4 r} \operatorname{Prprice}_{\mathrm{t}-\mathrm{r}}+\sum_{i=1}^{n} \lambda_{5 n}$ Xvalue $_{\mathrm{t}-1}+\sum_{m=1}^{p} \lambda_{6 m}$ Wexpvol $_{\mathrm{t}-\mathrm{m}}+\mathrm{U}_{1 \mathrm{t}}$

Wexpvol $_{\mathrm{t}}=\mathrm{l}_{0}+\sum_{m=1}^{p} \mathrm{l}_{1 i}$ Wexpvol $_{\mathrm{t}-\mathrm{m}}+\sum_{j=1}^{p} \mathrm{l}_{2 j}$ Exchrate $_{\mathrm{t}-\mathrm{j}}+\sum_{k=1}^{p} \mathrm{l}_{3 k} \operatorname{Prod}_{\mathrm{t}-\mathrm{k}}+\sum_{r=1}^{p} \mathrm{l}_{4 r}$ Prprice $_{\mathrm{t}-\mathrm{r}}++\sum_{i=1}^{p} \mathrm{l}_{5 n}$ Wexprice $_{\mathrm{t}-1}+\sum_{i=1}^{n} \mathrm{l}_{6 m}$ Xvalue $_{\mathrm{t}-1}+\mathrm{U}_{1 \mathrm{t}}$

where $\beta, \alpha, \Upsilon, \delta, \lambda$ and $l$ are parameters.

Second, if the variables in this study are cointegrated, the following VECM would be used:

$\Delta$ Xvalue $_{\mathrm{t}}=\beta_{1}+\sum_{i=1}^{p} \alpha_{11, l} \Delta$ Xvalue $_{\mathrm{t}-\mathrm{l}}=\sum_{j=1}^{p} 12, \mathrm{l} \Delta$ Exchrate $_{\mathrm{t}-\mathrm{l}}+\sum_{k=1}^{p} \delta_{13, l} \Delta$ Prod $_{\mathrm{t}-1}+\sum_{r=1}^{p} \lambda_{14, l} \Delta$ Prprice $_{\mathrm{t}-\mathrm{l}}+$ $\sum_{n=1}^{p} \mathrm{l}_{15, l} \Delta$ Wexprice $_{\mathrm{t}-1}+\sum_{m=1}^{p} \phi_{16} \Delta \mathrm{Wexpvol}_{\mathrm{t}-1}+\mathrm{p}_{1} \mathrm{ECT}_{\mathrm{t}-1}+\pi_{\mathrm{t}}$

$\Delta$ Exchrate $_{\mathrm{t}}=\beta_{2}+\sum_{i=1}^{p} \alpha_{21, l} \Delta$ Exchrate $_{\mathrm{t}-1}+\sum_{j=1}^{n} \quad 22, \mathrm{~L} \Delta$ Xvalue $_{\mathrm{t}-1}=\sum_{k=1}^{p} \delta_{23, l} \Delta$ Prod $_{\mathrm{t}-1}+\sum_{r=1}^{p} \lambda_{24, l} \Delta$ Prprice $_{\mathrm{t}-1}+$ $\sum_{n=1}^{p} \mathrm{l}_{25, l} \Delta \mathrm{Wexprice}_{\mathrm{t}-1}+\sum_{m=1}^{p} \phi_{26} \Delta \mathrm{Wexpvol}_{\mathrm{t}-1}+\mathrm{p}_{2} \mathrm{ECT}_{\mathrm{t}-1}+\pi_{\mathrm{t}}$

$\Delta \operatorname{Prod}_{\mathrm{t}}=\beta_{3}+\sum_{k=1}^{p} \alpha_{31, i} \Delta \operatorname{Prod}_{\mathrm{t}-1}+\sum_{i=1}^{n} \quad 32, \mathrm{~L} \Delta$ Xvalue $_{\mathrm{t}-1}=\sum_{j=1}^{p} \delta_{33, l} \Delta$ Exchrate $_{\mathrm{t}-1}+\sum_{r=1}^{p} \lambda_{34, l} \Delta$ Prprice $_{\mathrm{t}-1}+$ $\sum_{n=1}^{p} \mathrm{l}_{35, l} \Delta$ Wexprice $_{\mathrm{t}-1}+\sum_{m=1}^{p} \phi_{36} \Delta \mathrm{Wexpvol}_{\mathrm{t}-1}+\mathrm{p}_{3} \mathrm{ECT}_{\mathrm{t}-1}+\pi_{\mathrm{t}}$

$\Delta$ Prprice $_{\mathrm{t}}=\beta_{4}+\sum_{r=1}^{p} \alpha_{41, l} \Delta$ Prprice $_{\mathrm{t}-1}+\sum_{j=1}^{p} \quad 42, \mathrm{l} \Delta$ Exchrate $_{\mathrm{t}-1}+\sum_{k=1}^{p} \delta_{43, l} \Delta$ Prod $_{\mathrm{t}-1}+\sum_{i=1}^{n} \lambda_{44, l} \Delta$ Xvalue $_{\mathrm{t}-\mathrm{l}}+$ $\sum_{n=1}^{p} \mathrm{l}_{45, l} \Delta$ Wexprice $_{\mathrm{t}-1}+\sum_{m=1}^{p} \phi_{46} \Delta \mathrm{Wexpvol}_{\mathrm{t}-1}+\mathrm{p}_{4} \mathrm{ECT}_{\mathrm{t}-1}+\pi_{\mathrm{t}}$

$\Delta$ Wexprice $_{\mathrm{t}}=\beta_{5}+\sum_{i=1}^{p} \alpha_{51} \Delta$ Wexprice $_{\mathrm{t}-1}+\sum_{j=1}^{p} \quad 52, \mathrm{l} \Delta$ Exchrate $_{\mathrm{t}-1}+\sum_{k=1}^{p} \delta_{53, l} \Delta$ Prod $_{\mathrm{t}-1}+\sum_{r=1}^{p} \lambda_{54, l} \Delta$ Prprice $_{\mathrm{t}-1}+$ $\sum_{i=1}^{n} \mathrm{l}_{55, \mathrm{l}} \Delta \mathrm{Xvalue}_{\mathrm{t}-\mathrm{l}}+\sum_{m=1}^{p} \phi_{56} \Delta \mathrm{Wexpvol}_{\mathrm{t}-1}+\mathrm{p}_{5} \mathrm{ECT}_{\mathrm{t}-1}+\pi_{\mathrm{t}}$

$\Delta$ Wexpvol $_{\mathrm{t}}=\beta_{6}+\sum_{m=1}^{p} \alpha_{61} \Delta$ Wexpvol $_{\mathrm{t}-1}+\sum_{j=1}^{p} \quad 62, l \Delta$ Exchrate $_{\mathrm{t}-1}+\sum_{k=1}^{p} \delta_{63, l} \Delta$ Prod $_{\mathrm{t}-1}+\sum_{r=1}^{p} \lambda_{64, l} \Delta$ Prprice $_{\mathrm{t}-1}+$ $\sum_{i=1}^{p} \mathrm{l}_{65, l} \Delta$ Wexprice $_{\mathrm{t}-1}+\sum_{i=1}^{n} \mathrm{l}_{66, l} \Delta$ Xvalue $_{\mathrm{t}-1} \mathrm{p}_{6} \mathrm{ECT}_{\mathrm{t}-1}+\pi_{\mathrm{t}}$

where, ECT is the error correction term; the cointegration regression residual estimates. A negative and significant coefficient indicates that past equilibrium errors influence current outcomes. The individual's coefficients of the difference terms capture the short-run dynamics.

One of the challenges that researchers may face when estimating a VAR model is determining the appropriate lag order. In this study, we consider the Schwarz (Schwarz, 1978) and Hannan-Quinn (Hannan-Quinn, 1979) lag order selection criteria. The Granger Causality test (C.W.Granger, 1988) is also used in this study to examine the relationship between variables. We also run some diagnostic tests on model's residuals. For the possibility of autocorrelation, we used Lagrange-multiplier test (LM) and Jarque-Bera test (JB).

\subsection{Data Description and Source}

The annual data used in this study come from FAOSTAT, GBoS (The Gambia Bureau of Statistics) database, and World Bank Indicators, and cover the years 1961 to 2018. The producer price and the world export price were booth calculated in USD dollars per ton, while the value of the exports were calculated in USD dollars. Groundnut production and global demand were both calculated in tons. To account for proliferative effect of time series, all data were represented logarithmically in the study. The summary statistics for all variables used in this analysis can be found in Table 3.

Table 3. Summary statistics

\begin{tabular}{|l|l|l|l|l|l|l|}
\hline & Exearnings & Exchrate & Prod & Pdprice & Wexprice & Wexpvol \\
\hline Mean & $8,058.448$ & 15.219 & $1005,287.653$ & 217.889 & $1,030.601$ & $1,089,718.55$ \\
\hline Max & 27,395 & 48.151 & 151,500 & 486.5 & $2,318.163$ & $1,989,591.00$ \\
\hline Min & 456 & 1.702 & 45,822 & 85 & 300 & $638,514.00$ \\
\hline Std. Dev & 6002.872 & 14.107 & $27,629.760$ & 93.128 & 522.359 & $352,466.21$ \\
\hline Skewness & 1.43 & 0.911 & -0.12 & 0.817 & 1.11 & 1.06 \\
\hline Kurtosis & 1.63 & -0.42 & -0.91 & 0.646 & 0.26 & 0.47 \\
\hline
\end{tabular}

Source: FAOSTAT, 2021

\section{Results and Discussion}

5.1 Stationarity

The empirical study starts with testing the time series variables' stationary as a precondition for cointegration, which can be done with either VAR or VECM. The stationary of the time series data was examine using the Augmented Dickey-Fuller (ADF) unit root test. Table 4 shows the approximate results of the unit root evaluation. Because calculated test statistics could not reject the null hypothesis of non-stationarity, the results indicate that 
no time series variables appear to be stationary at the variable level. This indicates that the variables in the level data are non-stationary. As a result, it implies that statonarity must be checked at a higher order differencing. When the first differences of the variables are considered in Table 4, the null hypothesis of unit root is rejected at 5\% level of significant. Therefore, the differences become stationary and as a result the associated variables are integrated of order one, I(1).

It is well known that the lag order of the VAR model can have a significant impact on the VAR analysis. When the differences in lag order are large enough, they can affect the interpretation of VAR estimates.

Table 4. Results of Augmented Dickey Fuller unit root test results

\begin{tabular}{|l|l|l|c|}
\hline \multirow{2}{*}{ Variables } & \multicolumn{2}{|c|}{ Level Data } & \multirow{2}{*}{ Conclusion } \\
\cline { 2 - 3 } & \multicolumn{1}{|c|}{ Constant } & \multicolumn{1}{|c|}{ Constant with trend } & \\
\hline LogExvalue & -1.87 & -4.16 & Non-stationary \\
\hline LogExchrate & -0.371 & -2.93 & Non-stationary \\
\hline LogProd & -3.60 & -3.54 & Non-stationary \\
\hline LogPrprice & -1.08 & -4.41 & Non-stationary \\
\hline Log Wexprice & -2.14 & -3.09 & Non-stationary \\
\hline LogWexpvol & 0.106 & -2.16 & Non-stationary \\
\hline \multicolumn{1}{|c|}{ First differences } & Stationary \\
\hline LogExvalue & $-4.16^{* *}$ & Stationary \\
\hline LogExchrate & -1.87 & $-2.93^{* *}$ & Stationary \\
\hline LogProd & -0.37 & $-3.54^{* *}$ & Stationary \\
\hline LogPrprice & -3.60 & $-4.41^{* *}$ & Stationary \\
\hline Log Wexprice & -1.08 & $-3.09^{* *}$ & Stationary \\
\hline LogWexpvol & -2.14 & $-2.16^{* *}$ & Pary \\
\hline
\end{tabular}

Note: Xvalue: export value; EXchrate: nominal exchange rate; Prod: production; Pdprice: producer price; Wexprice: world export price; Wexpvol: world demand; log: natural logarithm; and ${ }^{* *}$ indicates statistically significant at $5 \%$.

The optimal lag selection considered in this study by using the Hannan-Quinn(HQ) and Schwarz (SC).Table 5 shows the Stata output for lag order selection based on each criterion.

Table 5. VAR lag order selection

\begin{tabular}{|l|l|l|l|l|l|}
\hline Lag order & LR & FPE & AIC & SC & HQ \\
\hline 0 & N/A & $1.5 \mathrm{e}+37$ & 102.66 & 102.999 .19 & 102.75 \\
\hline 1 & $304.18^{*}$ & $9.0 \mathrm{e}+34^{*}$ & $97.36^{*}$ & $99.19^{*}$ & $98.13^{*}$ \\
\hline 2 & 58.25 & $1.3 \mathrm{e}+35$ & 97.81 & 100.94 & 98.98 \\
\hline 3 & 67.76 & $1.9 \mathrm{e}+35$ & 97.90 & 102.48 & 99.61 \\
\hline 4 & 96.30 & $1.8 \mathrm{e}+35$ & 97.50 & 103.38 & 99.60 \\
\hline
\end{tabular}

Note: LR: sequential modified test statistics; FPE: final prediction error; AIC: Akaike information criterion; SC: Schwarz information criterion; HQ: Hannan-Quinn information criterion; and * indicate optimal lag criteria.

\subsection{Cointegration}

After determining that the variables are non-stationary at the level, stationary at the first difference, and that the series are integrated of order one. The cointegration relationship between them is determined using Johansen's maximum likelihood (ML) test. The results of the cointegration test $\left(\lambda_{\text {trace }}\right.$ and $\left.\lambda_{\max }\right)$ show that the maximum test value was less than $5 \%$ critical value at one cointegrating vector $(\mathrm{R} \leq 1)$ for both trace test and maximum-Eigen value test. As a result, the null hypothesis of one cointegrating equations cannot be rejected, and the results show that the time series variables (export value, exchange rate, production, producer price, world export price, and world demand) are integrated, as shown in Table 6, and the study concludes that a long run equilibrium relationship among the variables may exist.

Table 6. Johansen Cointegration Test

\begin{tabular}{|l|l|l|l|l|}
\hline Null hypothesis & Trace statistic & $5 \%$ Critical value & Max Eigenvalue & $5 \%$ Critical value \\
\hline $\mathrm{H}_{0}: \mathrm{r}=0$ & 96.89 & 94.15 & 42.54 & 39.37 \\
\hline $\mathrm{H}_{0}: \mathrm{r} \leq 1$ & $54.34 * *$ & 68.52 & $23.53 * *$ & 33.46 \\
\hline $\mathrm{H}_{0}: \mathrm{r} \leq 2$ & 30.82 & 47.21 & 14.79 & 27.07 \\
\hline $\mathrm{H}_{0}: \mathrm{r} \leq 3$ & 16.04 & 29.68 & 10.92 & 20.98 \\
\hline $\mathrm{H}_{0}: \mathrm{r} \leq 4$ & 5.12 & 15.41 & 5.06 & 14.07 \\
\hline $\mathrm{H}_{0}: \mathrm{r} \leq 5$ & 0.06 & 3.76 & 0.06 & 3.76 \\
\hline
\end{tabular}

Note: $r$ denotes the number of cointegrating vectors; ${ }^{* *}$ indicates statistically significant at $5 \%$.

Given the existence cointegration, we must employ VECM expressed by equations (11) to (16). The VECM is used to analyze the factors affecting groundnut exports in The Gambia and to determine the causality between 
the factors. The Vector Error Correlation Model provides us with short-run dynamics and as well as long-run estimates.

The short-run findings reveals that nominal exchange rate and the producer's price are factors affecting groundnut exports in The Gambia (with the export value-Xvalue as the dependent variable of interest). The nominal exchange rate was found to have positive sign $(0.27)$ and statistically significant at $10 \%$ level, indicating that the nominal exchange rate is a significant factor affecting groundnut exports earnings in The Gambia. This means that a $1 \%$ depreciation of the nominal exchange rate (or $1 \%$ increase in the value of the USD) will increase export earnings by $0.27 \%$ in the short-run. This is consistent with the findings of other studies such as Agasha (2009), Allaro (211) and Achille et al. (2020).

Similarly, the producer price was found to have the expected positive sign $(0.55)$ and is statistically significant at the $10 \%$ level. This means that a $1 \%$ increase in farm gate price will increase export earnings by $0.55 \%$ in the short-run. This finding is consistent with Achille et al. (2020), who reported that an increase in producer's price of sesame seed is associated with an increase in export earnings in Burkina Faso.

Table 7. Estimation of the VECM

\begin{tabular}{|c|c|c|c|c|c|c|}
\hline \multicolumn{7}{|c|}{ Short-run dynamics (one lag included) } \\
\hline $\begin{array}{l}\text { Dependent } \\
\text { variables }\end{array}$ & $\Delta \log$ Exvalue & $\Delta \log E x c h r a t e$ & $\Delta \log$ Prod & $\Delta \log$ Prprice & $\Delta \log W$ exprice & $\Delta \log W e x p v o l$ \\
\hline$\Delta \log$ Exvalue & $\begin{array}{l}-0.29 \\
(-2.01)\end{array}$ & $\begin{array}{l}0.004 \\
(0.14)\end{array}$ & $\begin{array}{l}-0.26 \\
(-0.34)\end{array}$ & $\begin{array}{l}0.08 * * \\
(-2.98)\end{array}$ & $\begin{array}{l}0.03 \\
(0.35)\end{array}$ & $\begin{array}{l}0.06 \\
(0.72)\end{array}$ \\
\hline$\Delta \log$ Exchrate & $\begin{array}{l}0.27 * \\
(2.43)\end{array}$ & $\begin{array}{l}0.29 \\
(1.99)\end{array}$ & $\begin{array}{l}-0.19 \\
(-0.51)\end{array}$ & $\begin{array}{l}-0.24 * \\
(-1.67)\end{array}$ & $\begin{array}{l}0.13 \\
(0.31)\end{array}$ & $\begin{array}{l}-0.03 \\
(-0.28)\end{array}$ \\
\hline$\Delta \log$ Prod & $\begin{array}{l}0.31 \\
(0.31)\end{array}$ & $\begin{array}{l}-0.02 \\
(-0.41)\end{array}$ & $\begin{array}{l}-0.21 \\
(-1.31)\end{array}$ & $\begin{array}{l}0.15 * * \\
(2.38)\end{array}$ & $\begin{array}{l}-0.18 \\
(-1.00)\end{array}$ & $\begin{array}{l}0.01 \\
(0.29)\end{array}$ \\
\hline$\Delta \log$ Prprice & $\begin{array}{l}0.55^{*} \\
(2.32)\end{array}$ & $\begin{array}{l}-0.18 \\
(-1.44)\end{array}$ & $\begin{array}{l}0.36 \\
(1.09)\end{array}$ & $\begin{array}{l}0.34 * * \\
(2.69)\end{array}$ & $\begin{array}{l}-0.12 \\
(-0.84)\end{array}$ & $\begin{array}{l}-0.32 * \\
(-3.25)\end{array}$ \\
\hline$\Delta \log W e x p r i c e$ & $\begin{array}{l}0.19 \\
(0.67)\end{array}$ & $\begin{array}{l}-0.05 \\
(-0.87)\end{array}$ & $\begin{array}{l}-0.12 \\
(-0.88)\end{array}$ & $\begin{array}{l}-0.24 * * * \\
(-4.28)\end{array}$ & $\begin{array}{l}0.34 * * \\
(-2.71)\end{array}$ & $\begin{array}{l}0.05 \\
(1.29)\end{array}$ \\
\hline$\Delta \log W$ expvol & $\begin{array}{l}-0.77 \\
(-0.78)\end{array}$ & $\begin{array}{l}0.26 \\
(1.31)\end{array}$ & $\begin{array}{l}0.88^{*} \\
(1.71)\end{array}$ & $\begin{array}{l}0.04 \\
(0.22)\end{array}$ & $\begin{array}{l}0.24 \\
(0.42)\end{array}$ & $\begin{array}{l}-0.25 * \\
(-1.64)\end{array}$ \\
\hline ECT & $\begin{array}{l}-0.11 * \\
(-1.6)\end{array}$ & $\begin{array}{l}-0.002 \\
(-0.17)\end{array}$ & $\begin{array}{l}0.03 \\
(0.97)\end{array}$ & $\begin{array}{l}0.08 * * * \\
(6.0)\end{array}$ & $\begin{array}{l}-0.019 \\
(6.0)\end{array}$ & $\begin{array}{l}-0.02 \\
(-1.9)^{*}\end{array}$ \\
\hline \multicolumn{7}{|c|}{ Long -run Equilibrium } \\
\hline \multirow[t]{2}{*}{ logExvalue } & logExchrate & logProd & logPrprice & logWexprice & \multicolumn{2}{|l|}{ logWexpvol } \\
\hline & $\begin{array}{l}2.09 * * * \\
(4.5)\end{array}$ & $\begin{array}{l}2.94 * * * \\
(3.78)\end{array}$ & $\begin{array}{l}8.41 * * * \\
(6.83)\end{array}$ & $\begin{array}{l}-2.91 * * * \\
(-4.48)\end{array}$ & \multicolumn{2}{|l|}{$\begin{array}{l}-1.86 \\
(1.47) \\
\end{array}$} \\
\hline
\end{tabular}

Note: Numbers in the brackets $(\ldots)$ are $\mathrm{z}$ statistics, ${ }^{* * *}$ indicates statistically significant at $1 \%,{ }^{* *}$ statistically significant at $5 \%$ and ${ }^{*}$ statistically significant at $10 \%$.

Furthermore, the ECT coefficient $(-0.11)$ is statistically significant and negative. This means that past equilibrium errors play a role in deciding current outcomes, or the deviation from the long-run equilibrium are corrected for within the current year at the convergence speed of $0.11 \%$.

According to long-run estimates, the nominal exchange rate, groundnut production, producer's price and world export price of groundnut are all factors influencing groundnut exports in The Gambia. In the long-run, nominal exchange rate and producer's price, like in the short-run are major factors in determining exports. In the long-run, a $1 \%$ depreciation of nominal exchange rate (or $1 \%$ increase in the value of USD) will increase the value of The Gambia's exports by $2.9 \%$. Although variable production was not significant factor in short-run in determining groundnut export. However, the production of groundnut has long-run effect on export performance. A $1 \%$ increase in groundnut production is expected to result in a $2.94 \%$ increase in the value of groundnut export in The Gambia. This finding confirms Achille et al. (2020) finding that, in long-run, the nominal exchange rate and production are key determinants of sesame seed export in Burkina Faso. Again, as in the short run, producers' price remain a major factor in determining exports in the long run; a $1 \%$ increase in farm gate price results in an 8.41 percent increase in export value for The Gambia. The results confirms the findings of Amoro and Shen (2013), which, in the long-run reveals that farm gate price is a key determinant of cocoa and rubber exports in Cote d'Ivoire.

In contrast to the short-run, the world export price of groundnut is negative and significant. A $1 \%$ increase in world export prices reduces the value of exports by $2.91 \%$. Indeed, when prices rise, exporters are encourage to increase their output and expect higher profits. In equilibrium, however, they are hampered by the downward pressure on world prices, which makes groundnut cheaper on the international market and from other sources than the one offered by The Gambia 
Table 8. Short-run diagnostic test

\begin{tabular}{|l|l|l|}
\hline Test & \multicolumn{1}{|c|}{ LM } & \multicolumn{1}{c|}{ JB } \\
\hline Value & $0.774 * *$ & $0.047 * *$ \\
\hline Interpretation & No autocorrelation at lag order & VAR satisfies stability condition \\
\hline
\end{tabular}

Note: LM: Lagrange- multiplier test; JB: Jarque-Bera test; ${ }^{* *}$ indicates the test statistics is significant.

In addition, we also report Lagrange-multiplier test (LM test) and Jarque-Bera test (JB test) to complement the study. These diagnostic tests seek to test for lack of serial correlation of the residuals, robustness of estimated coefficients and the stability of coefficients across the model. The figures are shown in Table 8 .

\subsection{Causality}

The staionarity of the variables, cointegration between variables used, and significance of ECT all indicate that there is causality between the variables in the short-run and long-run. As a result, testing for causality will be useful and appropriate to identify for causal relationships between the variables. Therefore, the test result can help in identifying key pathways and key factors that influence exports value. The short run hypothesis: there is no short-run causality going from variable $\mathrm{X}$ to variable $\mathrm{Y}$. If the chi-square is statistically significant, the null hypothesis is rejected (causality is accepted). The Granger short-run causality test is used to determine the shortrun causality. The summary results of the Granger causality test are presented in Table 9.

In the short-run, the findings of causality test (see Table 9) indicate unidirectional causality from nominal exchange rate and producer price to export value. It implies that any increase in any of these factors causes an increase in the value of exports in The Gambia. The result also shows short-run unidirectional causality going from nominal exchange rate, production and world export price to producer price. This suggests that a rise in any of these variables causes a rise in producer price. A short-run unidirectional causality also exist between world export volume and production, and between producer price and world export volume.

In terms of long-run causality, the results reinforce the finding of long-run relationships among variables. There is a bidirectional causal relationship between export value and nominal exchange rate. The study also discovered bidirectional causality from nominal exchange rate to producer price, from world demand for groundnut to nominal exchange rate, and from world export price to producer price for The Gambia.

Table 9. Short-run causality tests

\begin{tabular}{|c|c|c|c|c|c|c|}
\hline \multicolumn{7}{|c|}{ Short-run causality (in first difference) } \\
\hline Dependent variables & logExvalue & logExchrate & $\log$ Prod & logPrprice & logWexprice & logWexpvol \\
\hline logExvalue & - & $(0.06)$ & $(0.51)$ & $(5.24)$ & $(0.32)$ & $(1.84)$ \\
\hline logExchrate & $(9.49) * *$ & - & $(0.05)$ & $(13.21) * *$ & $(0.26)$ & $(0.64)$ \\
\hline logProd & $(3.83)$ & $(0.36)$ & - & $(8.66)^{* *}$ & $(0.79)$ & $(2.15)$ \\
\hline logPrprice & $(0.82) *$ & $(3.11)$ & $(1.09)$ & - & $(0.26)$ & $(14.92) * *$ \\
\hline logWexprice & $(0.41)$ & $(2.66)$ & $(0.41)$ & $(20.31)^{* * *}$ & - & $(1.09)$ \\
\hline logWexpvol & $(2.54)$ & $(1.9)$ & $(4.75) *$ & $(2.53)$ & $(1.36)$ & - \\
\hline \multicolumn{7}{|c|}{ Long-run causality } \\
\hline logExvalue & - & $-0.50 * *$ & -0.12 & 0.11 & -0.15 & -0.17 \\
\hline logExchrate & $-0.26^{* *}$ & - & 0.09 & $1.41 * * *$ & -0.25 & $1.45 * * *$ \\
\hline logProd & -0.03 & 0.04 & - & -0.36 & 0.04 & 0.04 \\
\hline logPrprice & 0.01 & $0.28 * * *$ & -0.14 & - & $0.27 * * *$ & -0.09 \\
\hline logWexprice & -0.05 & -0.17 & 0.05 & $0.94 * * *$ & - & 0.39 \\
\hline logWexpvol & -0.01 & $0.22 * * *$ & 0.01 & -0.07 & 0.08 & - \\
\hline
\end{tabular}

Note: numbers between the brackets $(\ldots)$ are Chi-square statistics, ${ }^{* * *}$ indicates statistically significant at $1 \%$, statistically significant at $5 \%$ and ${ }^{*}$ statistically significant at $10 \%$.

\section{Conclusions and Policy Implications}

\subsection{Summary of Findings}

Using the VECM and time series data from 1961 to 2018, this study investigate the factors affecting groundnut exports in The Gambia. It has also used Granger causality test to examine the relationship between these determinants. The short-run result suggests that the nominal exchange rate and producer price all have significant impact on groundnut earnings in The Gambia. In the long-run, nominal exchange rate, production, producers price and world export price have all had a significant impact on groundnut earnings in The Gambia. Therfore, in the short and long-run, Gambia's groundnut exports are determined by both internal factors such as nominal exchange rate, production, and producer price, as well as external factor such as world export price.

The model's error correction term is found to statistically significant, implying a rapid convergence to equilibrium. The coefficient estimate of error correlation term in our model is $(-0.1108)$, implying the variables adjust to long run equilibrium at a speed of 11 percent per annum, confirming the validity of the variables' long- 
run relationship (equilibrium).

6.2 Conclusions and Recommendations

With the increasing demand of groundnut expected to continue, the study is seen as critical to the successful design and implementation of policies aimed at increasing The Gambia's groundnut export earnings. The study comes to the following conclusions:

To begin with, we found a bidirectional causality between the nominal exchange rate and the value of exports. According to trade and economic literature, an important factor determining a country's exports is the exchange rate. A policy aimed at depreciating the local currency may have an effect on groundnut export performance. In other words, an appreciation in the value of US dollar would boost exports.

Second, there is a bidirectional causal relationship between producer price and export earnings. The implication is that farmers' earnings are primarily determined by farm gate price. However, the large difference between the export price and farm gate price prevents farmers from earning high income. Therefore, ensuring proper transmission of export prices to an acceptable margin would benefits farmers by increasing their revenues and reducing economic fallout.

Third, it has been found that production has a significant influence on the value of groundnut exports. It implies that an increase in production leads to an increase in export earnings. Since groundnut is a cash crop in The Gambia, an increased revenue from groundnut exports would encourage farmers to increase production. The potential to increase production quantities is a factor that, in general, will increase groundnut export earnings. As a result, it is critical to increase production, which can be accomplished by increasing yields significantly, assisting farmers in a variety of ways, such as providing adapted financial credits, distributing farm inputs such as pesticide, modern technologies, fertilizers, herbicides, and improved seeds, and improving the quality of groundnut exported to meet international standards

Finally, this study found bidirectional causality between producer price and world demand for groundnut. This implies that when world demand picks up, producers prices are expected to rise in tandem with global prices. All things being equal, an increase in world demand raises farm gate price, thereby boosting farmers' revenues. Furthermore, world export price has a significant impact on producer price. Farmers' earning are mainly determine by farm gate price. As a result, any increase in world export price will translate into higher farm gate price and higher farm revenue.

\section{References}

Achille, K. W., Hsu, C. S., Chang, C. C., \& Hsu, S. H. (2020). Factors Affecting Sesame Seed Exports in Burkina Faso: The Vector Error Correction Approach.

Agasha, N. (2009). "Determinants of export growth rate in Uganda1987-2006." Uganda revenue authority, research and planning, Kampala, Uganda.

Allaro, H. B. (2011). Export performance of oilseeds and its determinants in Ethiopia. Journal of Cereals and Oilseeds, 2(1), 1-15.

Amoro, G., \& Shen, Y. (2013). The determinants of agricultural export: Cocoa and rubber in Cote d'Ivoire. International Journal of Economics and Finance, 5(1), 228-233.

Badiane, O., \& Kinteh, S. (1994). Trade pessimism and regionalism in African countries: The case of groundnut exporters (Vol. 97). Intl Food Policy Res Inst.

Balassa, B. (1965). Trade Liberalisation and "Revealed" Comparative Advantage. The Manchester School, 33(2), 99-123.

Boansi, D., OdilonKounagbéLokonon, B., \& Appah, J. (2014). Determinants of agricultural export trade: case of fresh pineapple exports from Ghana. Journal of Economics, Management and Trade, 1736-1754.

Boansi, D., Lokonon, B. O. K., and Appah, J. (2014). Co-integration Analysis of the Determinants of Cotton Lint Exports from Mali. Asian J. Agricultural Extension. Economics and Sociology, 3(6), 544-561.

Dercon, S. (1993). Peasant supply response and macroeconomic policies: cotton in Tanzania. Journal of African Economies, 2(2), 157-194.

Diaz Rios, L., \& Jaffee, S. (2008). Barrier, catalyst, or distraction? Standards, competitiveness, and Africa's groundnut exports to Europe.

Dickey, D., Jansen, D., and Thornton, D. (1991). A Primer on Cointegration With Application to Money and Income. Review, Federal Reserve Bank of St. Louis, 73(2), 58-78.

Diop, N., Beghin, J., \& Sewadeh, M. (2004). Groundnut policies, global trade dynamics, and the impact of trade liberalization. Global Trade Dynamics, and the Impact of Trade Liberalization (March 2004). World Bank Policy Research Working Paper, (3226).

Folawewo, A. O., \& Olakojo, S. A. (2010). Determinants of agricultural exports in oil exporting economy: empirical evidence from Nigeria. Journal of Economics Theory, 4(4), 84-92.

Food and Agriculture Organization (FAO) (2021). FAO database, Available Online [Accessed May 2021] 
Food and Agriculture Organization (FAO) (2020) http://www.fao.org/gambia/gambia-at-a-glance/en/ [Accessed May 2021]

Gambia Bureau of Statistics(GBoS) (2017) "Integrated Household Survey 2015/2016" https://www.gbosdata.org/about-us [Accessed May 2021]

Goldstein, M., \& Khan, M. S. (1978). The supply and demand for exports: a simultaneous approach. The review of economics and statistics, 275-286.

Granger, C. W. J. (1986). Developments in the study of cointegrated economic variables. In Oxford Bulletin of economics and statistics.

Granger, C. W. (1988). Some recent development in a concept of causality. Journal of econometrics, 39(1-2), 199211.

Hannan, E. J., \& Quinn, B. G. (1979). The determination of the order of an autoregression. Journal of the Royal Statistical Society: Series B (Methodological), 41(2), 190-195.

Johansen, S., and Juselius, K. (1990). Maximum Likelihood Estimation and Inference on Cointegration with Applications to the Demand for Money. Oxford Bulletin of Economics and statistics, 52(2), 169-210.

Kingu, J. (2014). Determinants of Tanzanian Agricultural Export. Developing Country Studies, 4(1), 91-104.

Morgan, J. (2007). Triumph of the Expert: Agrarian Doctrines of Development and the Legacies of British Colonialism. Athens: Ohio University Press.

Schwarz, G. (1978). Estimating the dimension of a model. Annals of statistics, 6(2), 461-464.

Uysal, O., \& Mohamoud, A. S. (2018). Determinants of export performance in East Africa countries. Chinese Business Review, 17(4), 168-178.

World Bank (2018), World Bank Database, Available Online [Accessed May 2021] 